Relations industrielles

Industrial Relations

\title{
Labour Studies Research Bulletin, Labour Studies Resource Center, Department of Political Science, Carleton University, 1981, 32 pp.
}

\section{James Thwaites}

Volume 36, numéro 4, 1981

URI : https://id.erudit.org/iderudit/029224ar

DOI : https://doi.org/10.7202/029224ar

Aller au sommaire du numéro

Éditeur(s)

Département des relations industrielles de l'Université Laval

ISSN

0034-379X (imprimé)

1703-8138 (numérique)

Découvrir la revue

Citer ce compte rendu

Thwaites, J. (1981). Compte rendu de [Labour Studies Research Bulletin, Labour Studies Resource Center, Department of Political Science, Carleton University, 1981, 32 pp.] Relations industrielles / Industrial Relations, 36(4), 958-958.

https://doi.org/10.7202/029224ar

Tous droits réservés @ C Département des relations industrielles de l'Universite Laval, 1981
Ce document est protégé par la loi sur le droit d'auteur. L’utilisation des services d'Érudit (y compris la reproduction) est assujettie à sa politique d'utilisation que vous pouvez consulter en ligne.

https://apropos.erudit.org/fr/usagers/politique-dutilisation/ 
dicales sur les lieux de travail, ce qui affaiblit considérablement la position du TUC dans ses rapports avec l'État.

S'il y a lieu d'émettre certaines réserves sur le trop peu d'attention accordée à certains aspects de la question, et aussi de noter que le cadre d'analyse un peu rigide tend parfois à rendre la discussion répétitive, il faut surtout retenir qu'il s'agit dans l'ensemble d'un ouvrage intéressant sur un sujet fascinant. Le professeur Ross Martin nous offre une recherche d'une très grande qualité sur le plan académique.

\section{Jacques BÉLANGER}

Université Laval

Labour Studies Research Bulletin, Labour Studies Resource Centre, Department of Political Science, Carleton University, 1981, $32 \mathrm{pp}$.

One of the most striking phenomena over the last few years has been the appearance of several research "bulletins", in such specialized fields as urban studies, leisure activities and labour studies. The Labour Studies Research Bulletin of Carleton University is the most recent of this trend, which attempts to find a form of expression between the ephemeral "newsletter" and the fullblown "scientific journal". It is the third of its kind in the labour field, having been preceeded by the CCLH's Bulletin on labour history and the RCHTQ's Bulletin RCHTQ on interdisciplinary labour research. Each of its predecessors found itself compelled to become quite elaborate as time went on, and this may also be the fate of the present publication. The former was finally swallowed up by the journal Labour/Le travailleur, cutting English-speaking readers off from such a medium, while the latter has maintained its presence among its Francophone readership. The logical question is whether the new bulletin is simply an attempt to fill the gap left by the CCLH's disappearance from the field or the result of completely independent factors.

In its origins, the second seems to be the answer. Founded by political scientists, it indicates the first concerted effort of that disci- pline to enter the field of labour research. The editors are quick to indicate, however, their intention to avoid monopoly and promote an interdisciplinary approach. In this respect, the Labour Studies Research Bulletin appears have much the same mission as its only competitor, the Bulletin RCHTQ. Another similarity is the preoccupation with purely labour studies, with a leaning toward the understanding and promotion of labour's case. The editorial statement is loud and clear as is the subsequent note of the Editorial Committee: "Against the background of mainstream industrial relations research, it is hoped that this publication will facilitate endeavours by labour researchers to produce alternative, progressive studies not only of but for workers and their unions". (Italics mine, p. 2) The feature essay, by Research Officer Geoff Bickerton of the C.U.P.W., picks up this same theme and strikes out at I.R. specialists, criticizing present orientations and suggesting new ones.

The sweeping generalizations of the Editorial Committee and its feature writer pose a problem for the future orientation of this new bulletin. Is organized labour looking for a vehicule to express its views? How will contributions of researchers, not entirely favourable to labour, be treated? Will there be a distinction between research and more polemical material published? Such questions indicate important problems to be resolved.

As regards other aspects of present content, the accent placed on abstracts ( 21 pages of a total of 32) seems exaggerated. A shorter integrated review essay would probably be better. Otherwise the material presented in this first issue is quite useful.

As a concluding comment, certain similarities between this bulletin and that of the RCHTQ suggest the possibility of formal or informal links between the two in their mutual interest. Good luck to the new team in their challenging task!

James THWAITES

Université Laval 